\title{
Pollen allergen skin test and specific lgE reactivity among Filipinos: a community-based study
}

Maureen Sabit ${ }^{1,2,3^{*}} \mathbb{0}$, Cecil Wong ${ }^{4}$, Agnes Andaya ${ }^{4}$ and John Donnie Ramos ${ }^{1,2,3}$

\begin{abstract}
Background: Despite the clinical importance of pollen allergens among Filipinos, few studies delve into the sensitization profiles of Filipinos against pollen allergens. This study determined the sensitization profile of Filipinos to pollen using skin prick test (SPT) and pollen-specific ELISA.

Methods: Pollen from fifteen selected plant sources was collected and extracted for use in sensitization tests. Volunteers were interviewed for their clinical history prior to blood sampling and SPT. The blood samples collected were assessed using Enzyme-Linked Immunosorbent Assay (ELISA).

Results: The best panel of pollen allergens for the skin prick test was Mangifera indica (64\%), Acacia auriculiformis (28\%), Mimosa spp. (25\%) Amaranthus spinosus (22\%), Lantana camara (20\%), Pilea microphylla (16\%) and Dichanthium aristatum (15\%). Young adults had more sensitizations to pollen than among early childhood and elderly. There were more allergic subjects that have rhinitis (61\%) than asthma (42\%) and atopic dermatitis (35\%). Pollen-specific IgE levels show low percent reactivity as compared to the skin test with Cocos nucifera obtaining the highest lgE reactivity (21\%).
\end{abstract}

Conclusions: Pollen allergens from both arboreal and herbaceous plants used in this study yielded positive reactivities for both skin tests and specific lgE tests.

Keywords: Pollen allergen, Enzyme-Linked Immunosorbent Assay, Skin prick tests, Sensitization

\section{Background}

Allergy is a hypersensitive reaction characterized by an immune-mediated inflammatory response to common environmental protein allergens that are deemed to be harmless in non-allergic individuals [1]. The global increase in the prevalence of allergic respiratory diseases and their effect on the quality of life of allergic patients is a health issue that needs immediate attention [2, 3]. In the Philippines, the reported overall prevalence of allergic rhinitis and allergic rhinoconjunctivitis is $20 \%$ and $14 \%$,

*Correspondence: mbsabit@ust.edu.ph; mhayen11@gmail.com

${ }^{2}$ Research Center for the Natural and Applied Sciences, Thomas Aquinas Research Complex, University of Santo Tomas, 1008 Manila, Philippines

Full list of author information is available at the end of the article respectively [4]; whereas, work absence due to asthma is reported at $46.6 \%$ [5]. Pollen is one of the most common and important sensitizing aeroallergens [6-9] that cause respiratory allergies such as allergic rhinitis, allergic asthma, and atopic dermatitis. Dissemination or dispersal of pollen, which occurs during a plant's pollination or flowering period, ensures survival and continuity of its lineage. Small, lightweight pollen, which is produced in copious amounts by anemophilous (wind-pollinated) plants, are the major allergens in the atmosphere. Several studies have shown that the incidence of pollinosis in urban areas is higher than the countryside due to unsuitable green space construction, urban heat island effect, and traffic pollution [10].

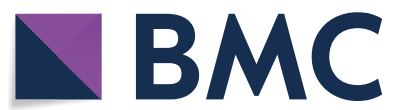

(c) The Author(s) 2020. This article is licensed under a Creative Commons Attribution 4.0 International License, which permits use, sharing, adaptation, distribution and reproduction in any medium or format, as long as you give appropriate credit to the original author(s) and the source, provide a link to the Creative Commons licence, and indicate if changes were made. The images or other third party material in this article are included in the article's Creative Commons licence, unless indicated otherwise in a credit line to the material. If material is not included in the article's Creative Commons licence and your intended use is not permitted by statutory regulation or exceeds the permitted use, you will need to obtain permission directly from the copyright holder. To view a copy of this licence, visit http://creativeco mmons.org/licenses/by/4.0/. The Creative Commons Public Domain Dedication waiver (http://creativecommons.org/publicdomain/ zero/1.0/) applies to the data made available in this article, unless otherwise stated in a credit line to the data. 
In tropical Asia, little information on pollen allergens is available [11], and information on the sensitization profiles of Filipino allergic patients to pollen allergens is limited. Sensitization to grass and weed pollen among Filipinos was reported earlier [12] and described anew by recent studies using immunobiological techniques $[13$, 14]. It is in this context that this study was conducted. Aqueous extracts of tree and weed pollen found to be abundant in the atmosphere were used to generate the sensitization profile of Filipinos using skin tests. This study aims to determine the total IgE and pollen specificIgE profiles of skin-test positive and negative subjects and correlate skin tests with pollen-specific IgE reactivity.

\section{Materials and methods}

\section{Study area and subjects}

Vegetation or the "green space" in a highly urbanized city of Metro Manila, is found only in parks, gardens, and trees planted along the road. Ten barangays near the vicinity of a pollen trap (situated within the University of Santo Tomas, Manila) were randomly chosen for this study. Prior to sampling, an approval from the UST Graduate School Institutional Ethics Committee Review Board was obtained. A total of 541 volunteers who have been living, working, or studying in the "University Belt" for more than 2 years prior to the conduct of this study were recruited. SPT-positive subjects were designated as cases while SPT-negative subjects were controls. All participants gave their informed consent prior to answering a standardized questionnaire. This questionnaire was adapted and modified by De Guia [15] from previous sources [16-18], and, validated these questionnaires for Filipino patients.

\section{Pollen collection}

The fifteen plants chosen as sources of pollen were previously reported as widespread in Metro Manila, and most are representative of the plant families with a high prevalence of airborne pollen [19]. Included were arboreal plants: Ptychosperma macarthurii (PTY), Cocos nucifera (COC), Mangifera indica (MAN), Acacia auriculiformis (ACA), Senna siamea (SEN), Lantana camara (LAN), Carica papaya (CAR), Terminalia catappa (TER), Eucalyptus spp. (EUC), Pinus kesiya (PIN), Dendrocnide meyeniana (DEN); and herbaceous plants: Mimosa spp. (MIM), Dichanthium aristatum (DIC), Pilea microphylla (PIL), and Amaranthus spinosus (AMA). Pollen samples were collected from the mature anthers of these plants and processed as described [20]. Flowers from trees and weeds were dried then passed through reducing sizes of mesh sieves $(150,75,50$ and $25 \mu \mathrm{m}$, respectively). The presence of pollen was confirmed under a stereomicroscope (BS-2030T Digital
Biological Trinocular Microscope). Pollen was stored in a tightly sealed container with a desiccant at $4{ }^{\circ} \mathrm{C}$.

\section{Pollen extraction, protein assay, and preparation of pollen extracts}

One gram (dry weight) of pollen was mixed with $10 \mathrm{~mL}$ diethyl ether and placed on a shaker overnight. The defatted pollen was centrifuged at $4000 \mathrm{rpm}$ for $10 \mathrm{~min}$, left to dry overnight, and mixed with $10 \mathrm{~mL}$ Phosphate Buffered Saline (PBS). The mixture was stirred overnight at $4{ }^{\circ} \mathrm{C}$ and centrifuged at $13,000 \mathrm{rpm}, 4^{\circ} \mathrm{C}$ for $30 \mathrm{~min}$. The supernatant was transferred to a dialysis tubing (6-8 kD MWCO, supplied by Spectrum Labs, USA) and passed through a $0.2 \mu \mathrm{m}$ Millipore filter (Whatman Puradisc 25, PES sterile). $1 \mathrm{~mL}$ aliquots of the dialyzed products were transferred to microcentrifuge tubes and stored at $-20{ }^{\circ} \mathrm{C}$ until use. The total protein content of the pollen was analyzed using Bio-Rad Protein Assay Kit II (Bio-Rad Laboratories Inc, Hercules, CA, USA). Each crude pollen aqueous extract was diluted with the appropriate amount of PBS to get a final concentration of $10 \mu \mathrm{g} / \mathrm{mL}$ for use in skin prick test (SPT) and pollenspecific IgE ELISA.

\section{Skin-prick test}

Volunteer selection was made carefully following the guidelines as described [1]. SPT was performed on all participants using a panel of 15 crude pollen extracts, house dust mites (HDM) Suidaisia pontifica (SUD), and Blomia tropicalis (BLO), and with histamine (0.1\%) in PBS and physiologic saline solution as positive and negative controls, respectively. A drop of each pollen extract was directly pricked on the participant's forearm using a $1 \mathrm{~mm}$-point sterile lancet. A white wheal measuring $\geq 3 \mathrm{~mm}$ in diameter and a red flare around the pricked skin area was interpreted as positive SPT [21].

\section{Immunobiological methods-Enzyme-Linked Immunosorbent Assay (ELISA)}

Five $\mathrm{mL}$ peripheral blood of study participants was collected in EDTA tubes and then centrifuged to separate the plasma. Samples were aliquoted and stored at $-20{ }^{\circ} \mathrm{C}$ until further use. The total IgE levels of cases $(\mathrm{n}=130)$ and controls $(\mathrm{n}=110)$ were determined following the manufacturer's protocol (Human IgE ELISA Core Kit, Komabiotech, South Korea). For pollen-specific IgE ELISA, $10 \mu \mathrm{g} / \mathrm{mL}$ aqueous pollen extracts diluted in carbonate-bicarbonate buffer were coated overnight at $4{ }^{\circ} \mathrm{C}$ onto the wells of high-binding microtiter plates (Corning Costar, NY, USA). Plates were blocked with 1\% BSA (Sigma-Aldrich, Saint Louis, MO, USA) in PBS for $1 \mathrm{~h}$ at room temperature. Plasma samples from both cases and controls were dispensed in 
duplicates onto the wells and incubated for $1 \mathrm{~h}$ at room temperature. Plates were incubated with $500 \times$ dilution of an HRP-conjugated goat anti-human IgE for $1 \mathrm{~h}$ at room temperature. Colorimetric reactions for all immunobiological tests were performed using TMB $\left(3,3^{\prime}, 5,5^{\prime}\right.$-Tetramethylbenzidine) and the reaction was stopped with $2 \mathrm{M} \mathrm{H}_{2} \mathrm{SO}_{4}$. Absorbance was read at $450 \mathrm{~nm}$ using Bio-Tek ELX800 ELISA reader (Tecan, Austria).

\section{Statistical analysis}

Data characteristics of test subjects (cases and controls) and positive reactions to different pollen allergens using skin prick test and specific IgE ELISA were presented as frequency (percentage) and compared using the Chi square test of homogeneity or Fisher's Exact test or z-test for two sample proportions. The diagnostic performance of SPT (positive and negative predictive values, specificity and sensitivity) with pollen, was computed. Spearman's correlation coefficient was used to test the association of the different pollen based on pollen-specific IgE ELISA results. Percent reactivity of pollen-specific IgE and sensitization profile among age groups were graphically represented. Frequency tables and graphs were created, and data analyzed using SPSS (v.20), MS Excel and/or GraphPad Prism 8.

\section{Results}

Five hundred forty-one study subjects from Metro Manila were recruited. Seven percent (7\%) of the study subjects were excluded because of non-cooperation, had taken antihistamine drugs before testing and backing out at the last minute. Of the $41 \%$ that were positive to skin tests $(n=205), 49 \%(n=101)$ were positive to both pollen and HDM, 14\% $(\mathrm{n}=29)$ were positive only to pollen, and $37 \%(\mathrm{n}=75)$ were positive only to HDM. Subjects that tested positive to pollen (cases, $n=130$ ), who self-reported to having allergic asthma (AA), allergic rhinitis (AR), and atopic dermatitis (AD), were referred to as allergic (79\%), while those who self-reported not to have allergic diseases were asymptomatic. Of the 373 skin-test negative subjects (to pollen), 110 were asymptomatic and referred to as controls. Table 1 shows the characteristics of the test subjects (cases and controls). Significant differences were shown in the percentage number of children (2-9 years old), young adults (20-40 years old), between gender and those with a family history of allergies between cases and controls. Of asymptomatic cases $(n=27), 37 \%$ have family members that were allergic. Allergic asthma (AA) and AR were commonly reported in either the father or mother of the cases. Several cases and controls have pets at

Table 1 Demographic characteristics of the respondents $(N=240)$

\begin{tabular}{|c|c|c|c|c|}
\hline Characteristic & Cases $(n=130)$ & Controls $(n=110)$ & Statistic & $\begin{array}{l}p \text {-value } \\
\text { (two- } \\
\text { tailed) }\end{array}$ \\
\hline \multicolumn{5}{|l|}{ Age group (years old) } \\
\hline $2-9$ & $8(6.15 \%)$ & $28(25.45 \%)$ & $-4.17^{b}$ & 0.001 \\
\hline $10-19$ & $29(22.31 \%)$ & $21(19.09 \%)$ & 0.61 & 0.541 \\
\hline $20-40$ & $67(51.54 \%)$ & $42(38.18 \%)$ & $2.07^{\mathrm{a}}$ & 0.038 \\
\hline $41-60$ & $23(17.69 \%)$ & $13(11.82 \%)$ & 1.27 & 0.205 \\
\hline$\geq 61$ & $3(2.31 \%)$ & $6(5.45 \%)$ & -1.28 & 0.202 \\
\hline Sex & & & $3.88^{\mathrm{a}}$ & 0.049 \\
\hline Male & $60(46.15 \%)$ & $37(33.64 \%)$ & & \\
\hline Female & $70(53.85 \%)$ & $73(66.36 \%)$ & & \\
\hline Family history of allergies & & & $13.97^{b}$ & 0.001 \\
\hline Yes & 65 (50.00\%) & $29(26.36 \%)$ & & \\
\hline No & 65 (50.00\%) & $81(73.64 \%)$ & & \\
\hline Presence of pets at home & & & 3.68 & 0.055 \\
\hline Yes & $81(62.31 \%)$ & 55 (50.00\%) & & \\
\hline No & $49(37.69 \%)$ & 55 (50.00\%) & & \\
\hline Smokes cigar, tobacco, or pipe & & & 2.78 & 0.095 \\
\hline Yes & $64(49.23 \%)$ & $66(60.00 \%)$ & & \\
\hline No & $66(50.77 \%)$ & $44(40.00 \%)$ & & \\
\hline
\end{tabular}

Data are presented as frequency (percentage) unless otherwise stated. Comparative analysis was conducted using the Chi Square Test of Homogeneity, Fisher's Exact test, or z-test for two sample proportions

a Significant at 0.05

b Significant at 0.01 
home, and there were no significant differences between them. The most common household pet were dogs (cases-68\%, controls-88\%), cats and birds (cases$10 \%$, controls $-12 \%)$ and a combination of dogs, cats, and birds (for cases only-22\%). Likewise, no significant differences were shown between cases and controls who self-reported to smoke or have family members who smoke. Allergic rhinitis (61\%) was prevalent among allergic cases, followed by AA (42\%) and AD (35\%).

Total IgE values of $\geq 100 \mathrm{IU} / \mathrm{mL}$ of subjects in cases and controls were $87 \%(n=113)$ and $55 \%(n=60)$, respectively. Based on Spearman's rho, there was no significant difference in the mean IgE levels between gender (cases and controls) and presence of allergic diseases in cases, although, the highest mean was obtained from male allergic subjects $(284.58 \mathrm{IU} / \mathrm{mL})$ and those with AA $(344.82 \mathrm{IU} / \mathrm{mL})$ and $\mathrm{AD}(324.89 \mathrm{IU} / \mathrm{mL})$.

Of the 11 species of arboreal plants used for SPT, most of the study subjects tested positive to three pollen sources: Mangifera indica (MAN), Acacia auriculiformis (ACA), and Lantana camara (LAN) as shown in Table 2. Study subjects were also positive to the pollen of herbaceous species, namely, Mimosa spp. (MIM), Amaranthus spinosus (AMA), Pilea microphylla (PIL), and Dichanthium aristatum (DIC). Wheal diameters of
6-10 $\mathrm{mm}$ were observed in subjects who tested positive to MIM and MAN. Based on sensitizations, $40 \%$ and $31 \%$ of positive subjects from skin tests and pollenspecific IgE ELISA, respectively, were sensitized to one allergen (monosensitization) while the rest of the test subjects were sensitized to two or more allergens (polysensitization). Figures 1 and 2 show the sensitization profile of allergic subjects across age groups. Male children (2-9 years old) have early sensitization than females. However, females show high sensitizations than males in all other age groups. Overall, there was an increase in the number of sensitizations to young adults (20-40 years old) and then gradually declined in the older age groups. Likewise, the number of polysensitized $(65 \%$ males, $56 \%$ females) subjects show similar tendencies while monosensitization ( $35 \%$ male, $44 \%$ female) were more evident in younger age groups. The sensitivity and specificity of the skin tests were $30 \%$ (95\% CI 25-35\%) and $83 \%$ (95\% CI $75-88 \%$ ), respectively. The prevalence of the allergic disease in the population was $69 \%$ with a positive predictive value of $79 \%$ ( $95 \%$ CI $71-85 \%$ ), and a negative predictive value of 34\% (95\% CI 30-39\%).

Significant differences in positive reaction to skin tests and pollen-specific IgE ELISA were shown in 10 pollen allergens (Table 2). Fifty-four percent (54\%) of skin

Table 2 Frequency of positive reactions to allergen among cases using skin prick test and specific IgE ELISA Test (N=130)

\begin{tabular}{|c|c|c|c|c|c|c|c|}
\hline \multicolumn{4}{|l|}{ Sources of pollen } & \multicolumn{2}{|c|}{ Frequency (Percentage) } & \multirow[t]{2}{*}{ Statistic } & \multirow{2}{*}{$\begin{array}{l}p \text {-value } \\
\text { (two- } \\
\text { tailed) }\end{array}$} \\
\hline Family & Scientific name & Code & Local Name (English; Filipino) & $\begin{array}{l}\text { Skin } \\
\text { Prick Test } \\
(N=130)\end{array}$ & $\begin{array}{l}\text { Specific } \\
\text { IgE ELISA } \\
(N=130)\end{array}$ & & \\
\hline \multicolumn{8}{|l|}{ Arboreal plants } \\
\hline Anacardiaceae & Mangifera indica & MAN & Mango; Manga & $83(63.85 \%)$ & $3(2.31 \%)$ & $10.53^{b}$ & 0.000 \\
\hline Arecaceae & Cocos nucifera & $\mathrm{COC}$ & Coconut; Niyog & $6(4.62 \%)$ & $27(20.77 \%)$ & $-3.91^{b}$ & 0.000 \\
\hline Arecaceae & Ptychosperma macarthurrii & PTY & MacArthurs's palm & $7(5.38 \%)$ & $20(15.38 \%)$ & $-2.67^{\mathrm{a}}$ & 0.008 \\
\hline Fabaceae & Acacia auriculiformis & ACA & Japanese acacia & $36(27.69 \%)$ & $5(3.85 \%)$ & $5.27^{\mathrm{b}}$ & 0.000 \\
\hline Fabaceae & Senna siamea & SEN & Thailand acacia & $5(3.85 \%)$ & $10(7.69 \%)$ & -1.33 & 0.184 \\
\hline Caricaceae & Carica papaya & CAR & Melon tree; Papaya & $12(9.23 \%)$ & $9(6.92 \%)$ & 0.681 & 0.495 \\
\hline Combretaceae & Terminalia catappa & TER & Tropical almond; talisai & $4(3.08 \%)$ & $3(2.31 \%)$ & 0.382 & 0.702 \\
\hline Myrtaceae & Eucalyptus spp. & EUC & Eucalyptus & $9(6.92 \%)$ & $15(11.54 \%)$ & -1.28 & 0.199 \\
\hline Pinaceae & Pinus kesiya & PIN & Benguet pine; Sahing & $10(7.69 \%)$ & $25(19.23 \%)$ & $-2.72^{\mathrm{a}}$ & 0.006 \\
\hline Urticaceae & Dendrocnide meyeniana & DEN & Lipa; Lipang kalabaw & $9(6.92 \%)$ & $12(9.23 \%)$ & -0.681 & 0.496 \\
\hline Verbenaceae & Lantana camara & LAN & Prickly lantana; Koronitas & $26(20.00 \%)$ & $1(0.77 \%)$ & $5.07^{b}$ & 0.000 \\
\hline \multicolumn{8}{|l|}{ Herbaceous plants } \\
\hline Amaranthaceae & Amaranthus spinosus & AMA & Thorny amaranth; Colitis & $28(21.54 \%)$ & $13(10.00 \%)$ & $2.55^{\mathrm{a}}$ & 0.011 \\
\hline Fabaceae & Mimosa spp. & MIM & Sensitive plant; Makahiya & $33(25.38 \%)$ & $12(9.23 \%)$ & $3.44^{\mathrm{b}}$ & 0.001 \\
\hline Poaceae & Dichanthium aristatum & DIC & Alabang grass; Alabang & $19(14.62 \%)$ & $6(4.61 \%)$ & $2.73^{\mathrm{a}}$ & 0.006 \\
\hline Urticaceae & Pilea microphylla & PIL & Gunpowder plant; Isang-dakot-na-bigas & $21(16.15 \%)$ & $4(3.07 \%)$ & $3.57^{\mathrm{a}}$ & 0.000 \\
\hline
\end{tabular}

Data are presented as frequency (percentage) unless otherwise stated. Comparative analysis was conducted using the Chi Square Test of Homogeneity, Fisher's Exact test, or z-test for two sample proportions

a Significant at 0.05

b Significant at 0.01 


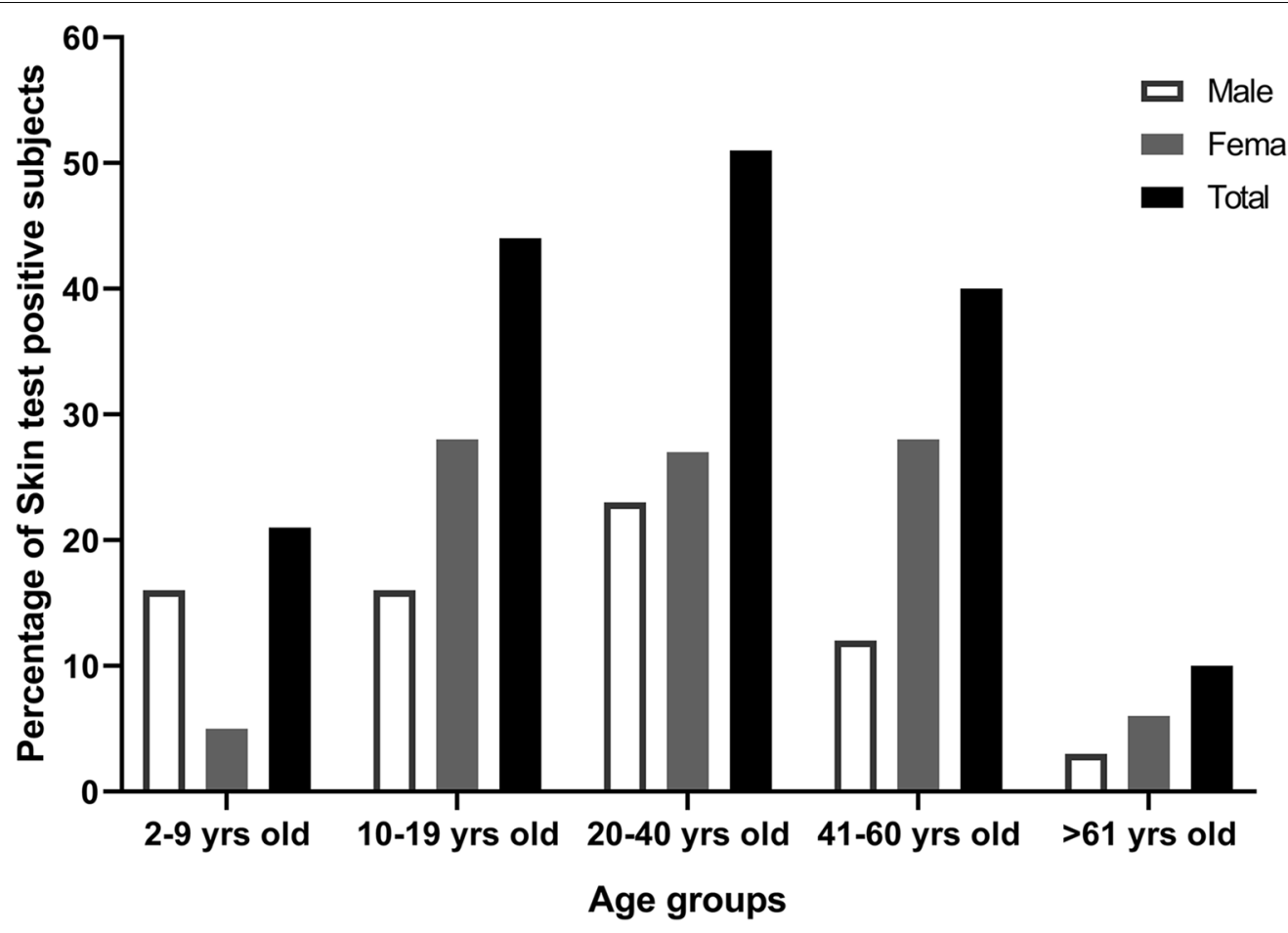

Fig. 1 Sensitization profile of allergic subjects across age groups: childhood (2-9 years old), adolescence (10-19 years old), young adults (20-40 years old), middle-aged adults (41-60 years old) and elderly (61 years old and above)

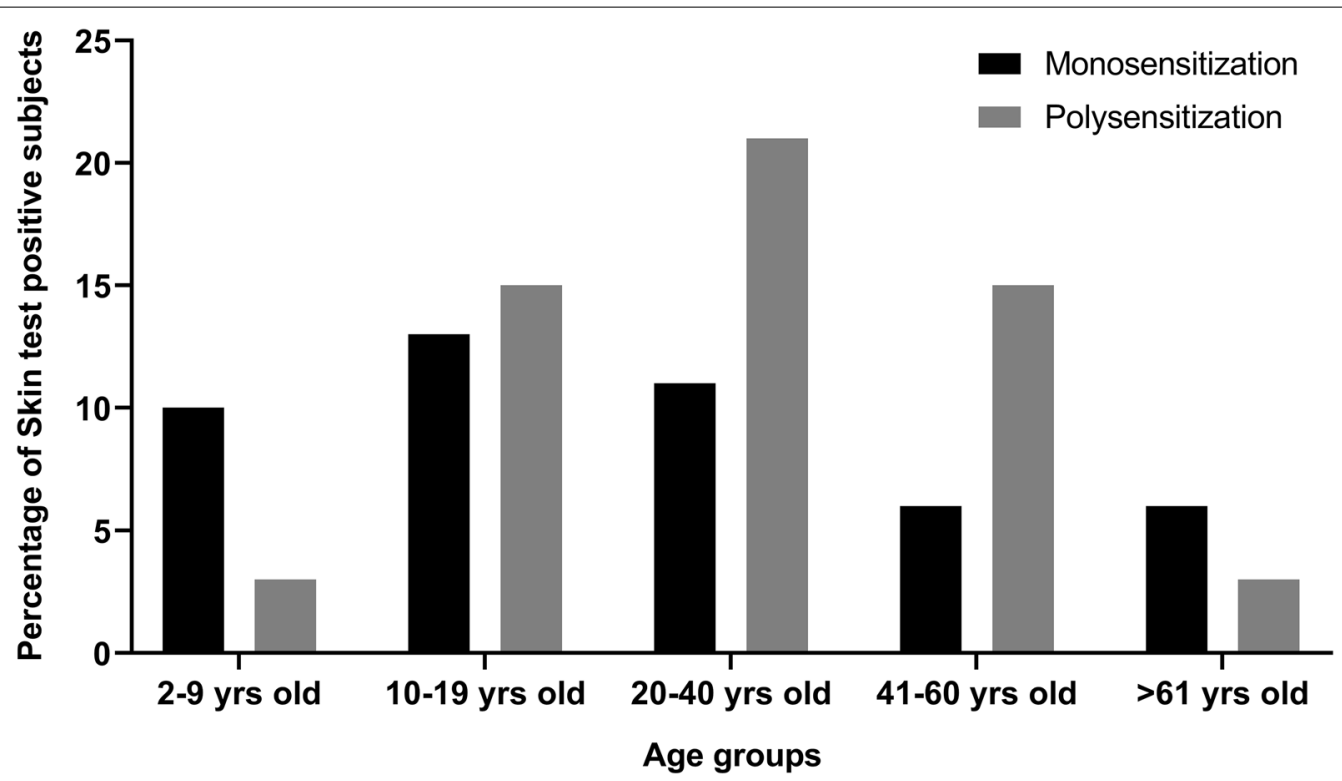

Fig. 2 Sensitization profile of allergic subjects across age groups: childhood (2-9 years old), adolescence (10-19 years old), young adults (20-40 years old), middle-aged adults (41-60 years old) and elderly (61 years old and above)

test positive cases were positive to pollen-specific IgE, $44 \%$ of which were asymptomatic. Subjects were more reactive to COC, PIN, and PTY among arboreal plants, and to AMA and MIM among herbaceous plants. These specific-IgE reactivities were based on cut-off values $(\overline{\mathrm{X}} \pm 2 \mathrm{SD})$ derived from 50 control subjects with a Total 
IgE of $\leq 100 \mathrm{IU} / \mathrm{mL}$ (Fig. 3). As shown in Table 3, MAN has significantly weak to moderate positive relationships to 11 pollen allergens. PIN, CAR, COC, EUC and ACA, PTY have weak to moderate to strong positive relationships to 10 and 9 pollen allergens, respectively. Significantly strong positive relationships were shown between EUC-PTY, EUC-PIN, PTY-PIN, and DIC-PIL. Species under the same family, e.g., Fabaceae (ACA, SEN, MIM), Arecaceae (COC, PTY), and Urticaceae (DEN, PIL) show significantly weak to moderate relationship, except for MIM that showed no relationship with ACA and SEN (Table 3).

\section{Discussion}

Recent sensitization studies in the Philippines were mostly on specific-IgE profiles of Filipinos to selected grass species (pollen) and house dust mites [13, 22]. Studies on SPT using pollen from grasses and weeds have also been described [12]. After a few decades, in this study, other sources of pollen, particularly from trees were utilized for both SPT and ELISA tests. Although M. indica, A. auriculiformis, and L. camara are entomophilous, there have also been published reports of their allergenicity $[9,23]$.
Skin prick tests (SPT), which is an essential procedure to confirm sensitization in IgE-mediated allergic disease in subjects with allergic rhinitis, asthma, and atopic dermatitis, can be performed from infancy to old age [24]. Likewise, SPT is considered a safe diagnostic procedure as the occurrence of systemic reaction has decreased and cases of fatalities were extremely low [25]. Aside from time, cost and safety, SPT had a high sensitivity to aeroallergens, mainly pollen and house dust mites [26].

Factors that influence the pollen threshold values for the development of allergic symptoms are as follows: time of the season, weather conditions, pollen allergenicity, air pollution and patient characteristics [27]. The recruitment of study subjects was done near the end of the flowering season (from April to June) when most of the trees (e.g. M. indica, C. nucifera, Eucalyptus spp., etc.) were in full bloom and bear fruits. The flowering of some plant sources are seasonal (e.g. M. indica, Eucalyptus spp., etc.) but most flower all throughout the year (e.g. C. nucifera, D. meyeniana, L. camara, etc.). As previously reported [19], the concentration of airborne pollen decrease near the end of May up to the first weeks of June, due to the increasing amount of rainfall

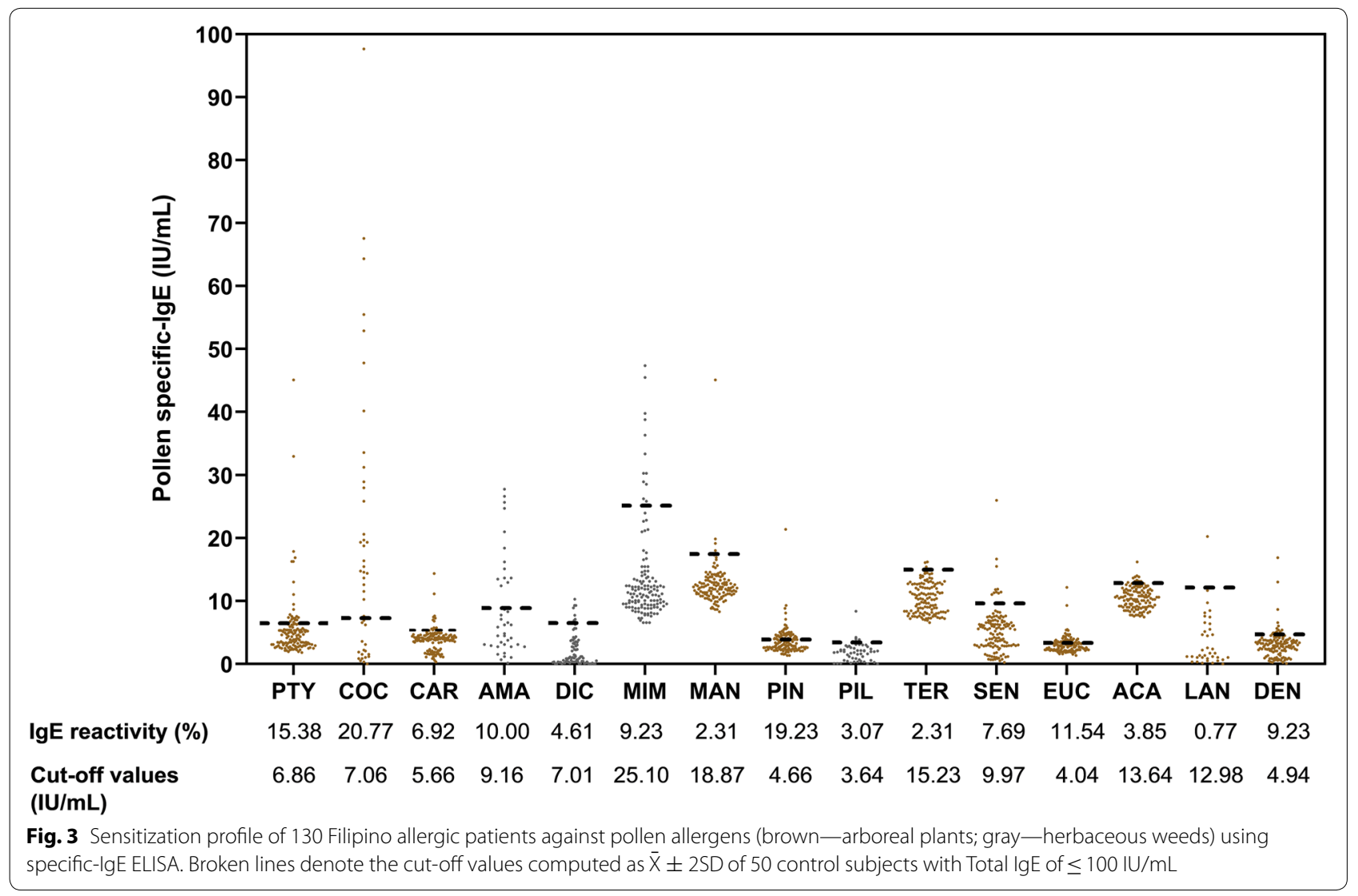


Table 3 Spearman's correlation of pollen-specific $\lg E(I U / m L)$ of different pollens $(N=130)$

\begin{tabular}{|c|c|c|c|c|c|c|c|c|c|c|c|c|c|c|c|}
\hline & MAN & $A C A$ & MIM & PIN & CAR & AMA & COC & PIL & DEN & TER & LAN & DIC & EUC & PTY & SEN \\
\hline 1. MAN & --- & --- & -- & -- & --- & --- & -- & -- & $\ldots$ & -- & --- & -- & --- & $\ldots$ & -- \\
\hline 2. ACA & $0.42^{b}$ & --- & - - - & --- & --- & -- & --- & --- &.- & -- & -- & -- & --- & --- & --- \\
\hline 3. MIM & $0.22^{a}$ & -0.05 & -- & -- & $\ldots$ & --- & --- & -- & $\ldots$ & --- & -- & -- & -- & --- & -- \\
\hline 4. PIN & $0.45^{b}$ & $0.31^{b}$ & $0.36^{b}$ & - - - & -- & $-\ldots$ & --- & -- & $-\ldots$ & --- & -- & -- & -- & -- & --- \\
\hline 5. CAR & $0.41^{b}$ & $0.30^{b}$ & 0.15 & $0.38^{b}$ & --- & -- & --- & -- & $\ldots$ & -- & -- & -- & -- & -- & - - \\
\hline 6. AMA & $0.23^{b}$ & -0.09 & $0.37^{b}$ & $0.26^{b}$ & $0.24^{b}$ & -- & -- & -- & $\ldots$ & -- & -- & -- & -- & -- & -- \\
\hline 7. COC & $0.25^{b}$ & $0.24^{b}$ & $0.21^{\mathrm{a}}$ & $0.27^{b}$ & $0.32^{b}$ & $0.26^{b}$ & --- & -- & $\ldots$ & --- & -- & -- & -- & --- & -- \\
\hline 8. PIL & -0.08 & -0.10 & 0.09 & $-0.24^{b}$ & $-0.30^{b}$ & 0.13 & 0.03 & -- & -- & --- & $-\cdots$ & -- & $\ldots$ & --- & --- \\
\hline 9. DEN & $0.47^{b}$ & $0.41^{b}$ & 0.16 & $0.39^{b}$ & $0.29^{b}$ & $0.21^{a}$ & $0.21^{a}$ & $0.20^{a}$ & -- & -- & -- & $\ldots$ & -- & $\ldots$ & - - \\
\hline 10.TER & $0.21^{a}$ & $0.44^{b}$ & $0.19^{a}$ & 0.10 & 0.06 & 0.06 & 0.09 & 0.14 & 0.16 & -- & --- & -- & --- & -- & --- \\
\hline 11. LAN & 0.14 & -0.02 & 0.13 & 0.09 & -0.06 & 0.14 & 0.04 & $0.38^{b}$ & $0.40^{b}$ & -0.11 & --- & -- & -- & -- & --- \\
\hline 12. DIC & 0.11 & -0.12 & $0.29^{b}$ & -0.04 & -0.17 & 0.15 & 0.08 & $0.51^{b}$ & 0.16 & 0.10 & $0.46^{b}$ & -- & -- & -- & -- \\
\hline 13. EUC & $0.33^{b}$ & $0.22^{a}$ & $0.19^{a}$ & $0.57^{b}$ & $0.22^{a}$ & $0.19^{a}$ & $0.19^{a}$ & $-0.18^{a}$ & 0.07 & 0.05 & 0.13 & 0.02 & $\cdots$ & -- & -- \\
\hline 14. PTY & $0.46^{\mathrm{b}}$ & $0.41^{b}$ & $0.25^{b}$ & $0.50^{\mathrm{b}}$ & $0.30^{b}$ & $0.22^{a}$ & $0.31^{b}$ & -0.11 & 0.02 & $0.38^{b}$ & -0.07 & 0.11 & $0.53^{b}$ & -- & 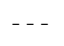 \\
\hline 15. SEN & $0.18^{a}$ & $0.18^{a}$ & 0.09 & -0.01 & $0.24^{b}$ & 0.06 & $0.22^{\mathrm{a}}$ & 0.14 & -0.12 & $0.55^{b}$ & -0.15 & $0.25^{b}$ & $0.20^{\mathrm{a}}$ & $0.48^{b}$ & --- \\
\hline
\end{tabular}

Categories for strength of relationships: +0.10 to $-0.10=$ No relationship; \pm 0.10 to $\pm 0.30=$ Weak relationship; \pm 0.30 to $\pm 0.50=$ Moderate Relationship; \pm 0.50 to $\pm 1.00=$ Strong Relationship (Cohen, 1988)

a Significant at 0.05

b Significant at 0.01

in the region. The high prevalence of allergic disease and high positive predictive value signify that there is a high probability that the amount of pollen in the air may have caused the allergic disease of the allergic subjects. Although skin tests in this study detected only almost one-third of the study subjects with allergic disease (low sensitivity), it has a high probability (specificity) that it can discriminate those who do not have an allergic disease in any of the pollen allergens used. Similarly, in another study, only $28.2 \%$ of their study subjects were sensitive to pollen allergens [8]. Allergic cases who tested negative to the skin tests require another test or another panel of pollen allergen to confirm results. Whereas, asymptomatics may develop allergic diseases later in life [28].

In this study, there's a discrepancy between results from SPT and pollen specific-IgE (sIgE), particularly that of $M$. indica. A recent study [29] made an assumption that tropical flora produces highly glycosylated allergens that hid or mask protein epitopes. As a result, IgE binds to these non-allergenic, pollen-derived carbohydrate epitopes instead of the allergenic protein allergens. This ultimately resulted in a specific-IgE negative response. Likewise, SPT-negative subjects that are positive to specific-IgE ELISA may be due to the presence of a crossreactive carbohydrate determinant or CCD [30-32], or the lack of pollen coat allergens, containing allergic epitopes [33]. More than 20\% of allergic patients that were asymptomatic have their IgE bind to carbohydrate compounds instead of the allergen [34]. In this study, some skin test-positive subjects were asymptomatic.

Ideally, a subject that has a positive clinical history would also have positive allergen-specific test results [35]. Instead, anomalies in having either positive or negative test results occur since the cause or presence of allergic disease are not revealed in all cases with positive clinical history. Even if a patient was clinically allergic to an allergen if there were no recent exposure, then allergic symptoms may be caused by something else; or, a patient may be sensitized to an allergen but not clinically allergic to it [36]. However, a significant number of allergic sensitizations may be missed if only one type of testing was performed [37]. Thus, SPT and specific-IgE testing should not be interpreted interchangeably but instead used as complementary [38].

Among Asians, exposure to pollen in urban communities is less than in rural areas. Studies suggest that early/childhood exposure to pollen (and keeping pets) can protect against allergic sensitization up to adulthood [39]. In contrast, this protective effect of rural living had changed due to a shift in urban lifestyle in rural areas [40]. Locally, pediatric patients showed that house dust mites and cockroaches were the main allergens, followed by Sorghum jalapense, A. spinosus, and $M$. indica [41]. Likewise, $A$. spinosus, $M$. indica, together with, Mimosa and $A$. auriculiformis were less allergenic to children. Although $M$. indica and $A$. auriculiformis belong to $<1 \%$ of the airborne pollen in Manila [19], its 
role in sensitization was significant. Overall, pollen from trees in Manila showed high sensitization rates among the sample population in this study. Previous studies of plants with low pollen counts, particularly from trees, demonstrate clinical significance [42, 43]. Alternatively, in this study, trees such as C. papaya and C. nucifera belonged to $>1 \%$ of airborne pollen in Manila [19] but showed low sensitization in skin tests. This contrasts with other studies, wherein C. papaya, and C. nucifera elicited a high response to SPT [44, 45], which may be attributed to geographical location, climate and allergen exposure.

A high percentage of test subjects in this study reported a history of rhinitis and asthma, which, are allergic diseases often associated with sensitization to aeroallergens [46]. Sensitization to pollen in this study peaked at the young adult stage (20-40 years old), and male sensitization started earlier than females, as is also shown in previous studies [38, 47, 48]. A longitudinal study of an urban population in Central Italy [28] revealed a significant increase in skin prick test reactivity, using the same sample population, across age groups and particularly in subjects $<40$ years old. At present, there is no accepted explanation for the sensitization shift between genders [38]. In a review assessing the impact of age on atopy, immunosenescence or a lower expression of IgE was observed as the cause of age-related decrease of positive skin test [49].

Exposure to environmental allergens increases over time as evidenced by the number of polysensitization, particularly in older age groups, as shown in this study. This polysensitization was also evident when pollen allergens were tested for cross-reactivity using an ELISA inhibition assay. Nearly all pollen, either closely or distantly related, had weak to strong associations and although of low percentage inhibition value, this may indicate the presence of cross-reactive proteins. Cross-reactivity between closely related plants reflects phylogeny, shared antigens or epitope binding sites, while cross-reactivity in distantly related plants, is due to minor allergens (e.g., profilins, lipid transfer proteins, and pathogenesis-related proteins) [50]. These minor allergens, called panallergens [51] play a significant role in the distribution of the allergic response to conserved epitopes of different allergenic sources [52].

In conclusion, pollen allergens from both arboreal and herbaceous plants used in this study yielded positive reactivities for both skin tests and specific IgE tests. Additionally, for a small community-based study population, it shows that Filipinos living in a highly urbanized city are allergenic to local pollen. Further sensitization studies should be done to assess if there would be differences between those living in urban and rural areas. Moreover, longitudinal studies comparing populations using the same tests and methods should be undertaken at different periods to have a more conclusive set of data. Likewise, an investigation of the genetic factors associated with pollen sensitization and response to therapy should be made.

\begin{abstract}
Abbreviations
SPT: Skin prick test; ELISA: Enzyme-Linked Immunosorbent Assay; PTY: Ptychosperma macarthurii; COC: Cocos nucifera; MAN: Mangifera indica; ACA : Acacia auriculiformis; SEN: Senna siamea; LAN: Lantana camara; CAR: Carica papaya; TER: Terminalia catappa; EUC: Eucalyptus spp.; PIN: Pinus kesiya; DEN: Dendrocnide meyeniana; MIM: Mimosa spp.; DIC: Dichanthium aristatum; PIL: Pilea microphylla; AMA: Amaranthus spinosus; PBS: Phosphate buffered saline; ISAAC: International Studies of Asthma and Allergy in Children; HDM: House dust mites; SUD: Suidaisia pontifica; BLO: Blomia tropicalis; AA: Allergic asthma; AR: Allergic rhinitis; AD: Atopic dermatitis.
\end{abstract}

\section{Acknowledgements}

The authors wish to thank the following individuals for their assistance and technical support: Nicole Andreanna Bulseco, Vanessa Maris Cariño, Romina Bianca Dinglasan, Rencie Espino, Raymond Michael Baladad, Ina Marie de Jesus, John Darrel Pamintuan, Emmanuel Tom Rosales, and Carol Navidad. Gratitude is also extended to the following institutions for the use of their facilities: University of Santo Tomas College of Science, University of Santo Tomas Graduate School, and University of Santo Tomas Research Center for the Natural and Applied Sciences.

\section{Authors' contributions}

MS designed the study, gathered all data, performed statistical analyses and interpretation of data, and drafted and revised the manuscript. CW contributed to data collection and interpretation of data. AA contributed to the design of the study and helped interpret data. JR contributed to the design of the study, helped in the interpretation of data and participated in the revision of the manuscript. All authors read and approved the final manuscript.

\section{Funding}

There were no funding agencies used in the conduct of this study.

\section{Availability of data and materials}

The datasets during and/or analysed during the current study are available from the corresponding author on reasonable request.

\section{Ethics approval and consent to participate}

All procedures performed in this study were in accordance with the ethical standards of the institutional and/or national research committee and with the 1964 Helsinki declaration and its later amendments or comparable ethical standards. An approval from the University of Santo Tomas Graduate School Institutional Ethics Committee Review Board was obtained (Protocol; number: G5-2015-173-R1) for this study.

\section{Consent for publication}

Not applicable.

\section{Competing interests}

The authors declare that they have no competing interests.

\section{Author details}

${ }^{1}$ The Graduate School, University of Santo Tomas, 1008 Manila, Philippines. ${ }^{2}$ Research Center for the Natural and Applied Sciences, Thomas Aquinas Research Complex, University of Santo Tomas, 1008 Manila, Philippines. ${ }^{3}$ Department of Biological Sciences, College of Science, University of Santo Tomas, 1008 Manila, Philippines. ${ }^{4}$ Department of Pediatrics, Section of Allergy and Clinical Immunology, University of Santo Tomas Hospital, 1008 Manila, Philippines. 
Received: 13 May 2019 Accepted: 5 August 2020

Published online: 12 August 2020

\section{References}

1. Douglass J, Hehir RO. Diagnosis, treatment and prevention of allergic disease: the basics. Med J Aust. 2006;185(4):228-33.

2. Pawankar R, Baena-Cagnani CE, Bousquet J, Canonica GW, Cruz A, Kaliner $M$, et al. State of world allergy report 2008: allergy and chronic respiratory diseases. World Allergy Organ J. 2008;1 (6 Suppl):S4-17.

3. Singh $A B$, Mathur $C$. An aerobiological perspective in allergy and asthma. Asia Pac Allergy. 2012;2:210-22.

4. Abong J, Kwong S, Alava H, Castor MA, De Leon J. Prevalence of allergic rhinitis in Filipino adults based on the National Nutrition and Health Survey 2008. Asia Pac Allergy. 2012;2:129-35.

5. Bousquet J, Khaltaev N, Cruz A. Allergic rhinitis and its impact on asthma (ARIA) 2008*. Allergy. 2008;63(Suppl 86):8-160.

6. Pawankar R, Bunnag C, Khaltaev N, Bousquet J. Allergic rhinitis and its impact on asthma in Asia Pacific and the ARIA Update 2008. World Allergy Organ J. 2012;5(Suppl 3):S212-7.

7. John A, Lee H, Lee F, Chng H. Allergen skin test and total lgE in adults with rhinitis in Singapore. Asian Pac J Allergy Immunol. 1996;14(1):9-12.

8. Liang K-L, Su M-C, Shiao J-Y, Wu S-H, Li Y-H, Jiang R-S. Role of pollen allergy in Taiwanese patients with allergic rhinitis. J Formos Med Assoc. 2010;109(12):879-85.

9. Ong TC, Lim SH, Chen X, Mohd Dali SD, Tan HTW, Lee BW, et al. Fern spore and pollen airspora profile of Singapore. Aerobiologia. 2011;28(2):135-51.

10. Jianan X, Zhiyun O, Hua Z, Xiaoke W, Hong M. Allergenic pollen plants and their influential factors in urban areas. Sheng Tai Xue Bao. 2007;27(9):3820-7.

11. Radauer $\mathrm{C}$, Breiteneder $\mathrm{H}$. Pollen allergens are restricted to few protein families and show distinct patterns of species distribution. J Allergy Clin Immunol. 2006;117:141-7.

12. Cua-Lim F, Payawal P, Laserna G. Studies on atmospheric pollens in the Philippines. Ann Allergy. 1978;40(2):117-23.

13. Cabauatan C, Ramos JD. Immunoglobulin E-binding reactivities of natural pollen grain extracts from selected grass species in the Philippines. Asia Pac Allergy. 2012;2:136-43.

14. Totaan E, Ramos JDA. IgE-binding activity of fifteen aqueous allergen extracts to selected filipino allergic individuals. Philipp Biot. 2009;12(1):45-57.

15. De Guia R. Polymorphisms of the IL4, MS4A2, and CD14 Genes and the risk of allergic disorders in a selected Filipino population (master's thesis). Manila: University of Santo Tomas; 2007.

16. International Primary Care Airways Group (IPAG). Chronic Airways Disease: A Guide for Primary Care Physicians. IPAG Diagnosis \& Management Handbook. 2005

17. The International Study of Asthma \& Allergies in childhood (ISAAC) Steering Committee. ISAAC Phase Two International Modules 1.1-4. 1998

18. Spector SL, Nicklas RA, Chapman JA, Bernstein IL, Berger WE, BlessingMoore J, et al. Symptom severity assessment of allergic rhinitis: part 1. Ann Allergy Asthm Immunol. 2003;91(2):105-14.

19. Sabit M, Ramos JD, Alejandro GJ, Galan C. Seasonal distribution of airborne pollen in Manila, Philippines, and the effect of meteorological factors to its daily concentrations. Aerobiologia. 2016;32(3):375.

20. Bulalacao L, Hernandez NP. Guide on the cultivation and management practices of allergy crops. Manila: National Research Council of the Philippines; 1999. p. 22-32.

21. Davies JM, Li H, Green M, Towers M, Upham JW. Subtropical grass pollen allergens are important for allergic respiratory diseases in subtropical regions. Clin Transl Allergy. 2012;2(1):4.

22. Ching MW, Yap JMG, Santos KCP, Ong CM, Ramos JDA. Correlation of total lgE, house-dust mite specific lgE and absolute eosinophils in an asthmatic pediatric population. Philipp Sci Lett. 2013;2014(6):241-8.

23. Mandal J, Chakraborty P, Roy I, Gupta-Bhattacharya S. Aerobiological, clinical and immunobiochemical studies on Lantana camara pollen and cross-reactivity with other Verbenaceae pollen species. Aerobiologia. 2012;28(2):107-19.
24. Heinzerling L, Mari A, Bergmann K-C, Bresciani M, Burbach G, Darsow $U$, et al. The skin prick test-European standards. Clin Transl Allergy. 2013:3(1):3.

25. Liccardi G, D’Amato G, Walter Canonica G, Salzillo A, Piccolo A, Passalacqua $G$. Systemic reactions from skin testing: literature review. J Investig Allergol Clin Immunol. 2006;16(2):75-8.

26. Antunes J, Borrego L, Romeira A, Pinto P. Skin prick tests and allergy diagnosis. Allergol Immunopathol. 2009;37(3):155-64.

27. de Weger LA, Bergmann KC, Rantio-Lehtimäki A, Dahl Å, Buters J Déchamp C, et al. Impact of Pollen. In: Sofiev M, Bergmann K, editors. Allergenic pollen: a review of the production, release, distribution and health impacts. Springer: Dordrecht; 2013. p. 161-215.

28. Dottorini ML, Bruni B, Peccini F, Bottini P, Pini L, Donato F, et al. Skin prick-test reactivity to aeroallergens and allergic symptoms in an urban population of central Italy: a longitudinal study. Clin Exp Allergy. 2007:37(2):188-96.

29. Cabauatan CR, Lupinek C, Scheiblhofer S, Weiss R, Focke-Tejkl M, Bhalla $\mathrm{PL}$, et al. Allergen microarray detects high prevalence of asymptomatic IgE sensitizations to tropical pollen-derived carbohydrates. J Allergy Clin Immunol. 2014;133(3):910-4.

30. Kumar R, Gupta N, Kanuga J, Kanuga M. A comparative study of skin prick test versus serum-specific IgE measurement in Indian patients with bronchial asthma and allergic rhinitis. Indian J Chest Dis Allied Sci. 2015:57(2):81-5.

31. Altmann F. Coping with cross-reactive carbohydrate determinants in allergy diagnosis. Allergo J Int. 2016;25:98-105.

32. Commins SP. Carbohydrates as allergens. Curr Allergy Asthma Rep. 2015;15(1):492

33. Bashir MEH, Ward JM, Cummings M, Karrar EE, Root M, Mohamed AB, et al. Dual function of novel pollen coat (surface) proteins: IgE-binding capacity and proteolytic activity disrupting the airway epithelial barrier. PLOS ONE. 2013;8(1):1-15.

34. Altmann F. The role of protein glycosylation in allergy. Int Arch Allergy Immunol. 2007;142(2):99-115.

35. Hamilton RG. Adkinson NF 23 Clinical laboratory assessment of IgE-dependent hypersensitivity. J Allergy Clin Immunol. 2003;111(2):S687-701.

36. Cox L, Williams B, Sicherer S, Oppenheimer J, Sher L, Hamilton R, et al. Pearls and pitfalls of allergy diagnostic testing: report from the American College of Allergy, Asthma and Immunology/American Academy of Allergy, Asthma and Immunology Specific IgE Test Task Force. Ann Allergy Asthma Immunol. 2008:101(6):580-92.

37. de Vos G. Skin testing versus serum-specific lgE testing: which is better for diagnosing aeroallergen sensitization and predicting clinical allergy? Curr Allergy Asthma Rep. 2014;430(14):2-8.

38. Mohammad HR, Belgrave D, Kopec Harding K, Murray CS, Simpson A, Custovic A. Age, sex and the association between skin test responses and IgE titres with asthma. Pediatr Allergy Immunol. 2016;27(3):313-9.

39. Bjerg A, Ekerljung L, Eriksson J, Naslund J, Sjolander S, Ronmark E, et al. Increase in pollen sensitization in Swedish adults and protective effect of keeping animals in childhood. Clin Exp Allergy. 2016;46(10):1328-36.

40. Rönmark E, Bjerg A, Perzanowski M, Platts-Mills T, Lundbäck B. Major increase in allergic sensitization in schoolchildren from 1996 to 2006 in northern Sweden. J Allergy Clin Immunol. 2009;124(2):357-63.

41. Estrella PF, Sumpaico M, Recto M, de Leon J, Castor MA. Sensitization pattern to aeroallergens and food allergens among pediatric patients with common allergic diseases. Allergy. 2013;68(o10-408):47-8.

42. Berna Dursun A, Çelik GE, Alan S, Münevver Pinar N, Mungan D, Misirligil Z. Regional pollen load: effect on sensitisation and clinical presentation of seasonal allergic rhinitis in patients living in Ankara, Turkey. Allergol Immunopathol. 2008;36(6):371-8.

43. Mandal J, Manna P, Chakraborty P, Roy I, Gupta-Bhattacharya S. Clinical and immunobiochemical characterization of airborne Delonix regia (Gulmohar tree) pollen and cross-reactivity studies with Peltophorum pterocarpum pollen: 2 dominant avenue trees from eastern India. Ann Allergy Asthma Immunol. 2009;103:515-24.

44. Chakraborty P, Ghosh D, Chowdhury I, Roy I, Chatterjee S, Chanda S, et al. Aerobiological and immunochemical studies on Carica papaya L. pollen: an aeroallergen from India. Allergy. 2005;60(7):920-6. 
45. Saha B, Bhattacharya SG. Aerobiology: 222 aerobiological and immunological studies on coconut pollen allergy. World Allergy Organ J. 2012;5(Suppl 2):S90

46. Farrokhi S, Gheybi MK, Movahed A, Tahmasebi R, Iranpour D, Fatemi A, et al. Common aeroallergens in patients with asthma and allergic rhinitis living in southwestern part of Iran: based on skin prick test reactivity. Iran J Allergy Asthma Immunol. 2015;14(2):133-8.

47. Schoos A-MM, Chawes BLK, Følsgaard NV, Samandari N, Bønnelykke K, Bisgaard $\mathrm{H}$. Disagreement between skin prick test and specific lgE in young children. Allergy. 2015;70(1):41-8.

48. Lee JE, Ahn JC, Han DH, Kim DY, Kim JW, Cho SH, et al. Variability of offending allergens of allergic rhinitis according to age: optimization of skin prick test allergens. Allergy Asthma Immunol Res. 2014;6(1):47-54.

49. Scichilone N, Callari A, Augugliaro G, Marchese M, Togias A, Bellia V. The impact of age on prevalence of positive skin prick tests and specific lgE tests. Respir Med. 2011;105(5):651-8.
50. Weber RW. Guidelines for using pollen cross-reactivity in formulating allergen immunotherapy. J Allergy Clin Immunol. 2008;122(1):219-21.

51. Migueres M, Dávila I, Frati F, Azpeitia A, Jeanpetit Y, Lhéritier-Barrand M, et al. Types of sensitization to aeroallergens: definitions, prevalences and impact on the diagnosis and treatment of allergic respiratory disease. Clin Transl Allergy. 2014;4:16.

52. Burastero SE. Pollen-cross allergenicity mediated by panallergens: a clue to the pathogenesis of multiple sensitizations. Inflamm Allergy Drug Targets. 2006;5(4):203-9.

\section{Publisher's Note}

Springer Nature remains neutral with regard to jurisdictional claims in published maps and institutional affiliations.
Ready to submit your research? Choose BMC and benefit from:

- fast, convenient online submission

- thorough peer review by experienced researchers in your field

- rapid publication on acceptance

- support for research data, including large and complex data types

- gold Open Access which fosters wider collaboration and increased citations

- maximum visibility for your research: over $100 \mathrm{M}$ website views per year

At BMC, research is always in progress.

Learn more biomedcentral.com/submissions 